\title{
The Narcissistic Appeal of Leadership Theories
}

\author{
Niklas K. Steffens ${ }^{1, *} \&$ S. Alexander Haslam ${ }^{1}$ \\ ${ }^{1}$ School of Psychology, The University of Queensland, Brisbane, Australia \\ * Corresponding author: Nik Steffens, School of Psychology, The University of Queensland, \\ Brisbane, QLD 4072, Australia; Tel: + (0) 6173364 9555; Email: n.steffens@uq.edu.au.
}

Accepted Manuscript for publication in American Psychologist:

Steffens, N. K., \& Haslam, S. A. (2020). The Narcissistic Appeal of Leadership Theories. American Psychologist. Advance online publication. http://dx.doi.org/10.1037/amp0000738

(C) 2020, American Psychological Association. This paper is not the copy of record and may not exactly replicate the final, authoritative version of the article. Please do not copy or cite without authors' permission. The final article will be available, upon publication, via its DOI: 10.1037/amp0000738

Acknowledgement: We thank Mark Chong for help with study design and data collection.

Supplementary Materials: Data and analysis script are accessible on the open science framework: https://osf.io/7a8ge/?view_only=None. 


\begin{abstract}
Leadership is one of the most researched topics in psychological and other social and behavioral sciences. It is routinely seen as vital to the success and vitality of various forms of collaborative activity not only in organizations but in society at large. This has provided the stimulus for a massive amount of theoretical and applied research and also supports a huge industry. But to whom does this body of work appeal? More specifically, does it appeal to people with a broad interest in advancing groups and society or to people who are primarily interested in promoting themselves? To answer this question, we explore the extent to which individuals' narcissism predicts their endorsement of leadership theories. Results provide empirical evidence that the more narcissistic people are, the more they find leadership theories appealing and the more interest they have in learning about the ideas behind particular theories. The predictive power of narcissism also holds when accounting for other variables (including demographic, Big Five traits, and ideological and motivational variables). We conclude that psychological theorizing about leadership can be a double-edged sword in so far as the lionization of leaders(hip) appeals to, and legitimizes, the tastes of a narcissistic audience.
\end{abstract}

Keywords: leadership; psychology of leadership; leadership theory; theory; narcissism. 


\section{Introduction}

Leadership has been a core topic in psychological and other social and behavioral sciences for the last 100 years. It is a flourishing field of science that has produced an extraordinarily large body of theoretical and empirical work (Dinh et al., 2014; Lord et al., 2017). The broad rationale for this work is that by better understanding leadership, researchers and practitioners will be in a better position to create a world in which good rather than bad forms of leadership prevail and hence a world that is itself good rather than bad. Indeed, because leadership is routinely defined as the process of motivating people to contribute to the achievement of group (or organizational) goals (e.g., Haslam, 2004; House et al., 2001; Rost, 2008; Smith, 1995) one might imagine that the pursuit of knowledge in this field is motivated by a noble interest in achieving 'a greater good'.

Appealing as this idea might be, over the years, a range of researchers have observed that leadership scholarship is not always as ennobling as one might hope. There are at least three inter-related reasons for this. First, one key issue is that while there is a strong tendency for researchers and practitioners to see leadership as an unalloyed good associated with "everything and anything that has a positive ring to it" (Alvesson et al., 2017, p. 8), leadership also has a "dark side" (Conger, 1990; Khoo \& Burch, 2008). Not least, this is because the goals that a group and its leader pursue can be toxic and malevolent as well as virtuous and worthy. Indeed, as work on the so-called "Hitler problem" suggests, one of the important skills of toxic leaders is precisely to convince followers to do evil in the name of good (Ciulla, 1995, 2005; Haslam et al., 2019).

Beyond, this, second, there is also the possibility that the study of leadership itself is toxic. Along these lines, Gemmill and Oakley (1992) have argued that leadership research necessarily perpetuates "an alienating social myth" that serves to pacify and mute the masses (i.e., followers) at the same time that it exalts and fetishizes the abilities of an elite few 
leaders. Relatedly, other researchers have argued that the science and industry of leadership is attuned to, and largely driven by, the needs of this elite — in particular, the need to explain their "specialness" and thereby to justify the spoils of leadership that they accrue (e.g., in the form of exorbitant CEO pay; Bennis, 1999; Gabaix \& Landier, 2008; Hollander, 1985; McGill \& Slocum, 1998).

Third, and related to both of the previous points, it is also possible that, like the trappings of leadership, ideas about leadership appeal primarily to particular individuals and that rather than this being individuals who are interested in the greater good, it is actually those who are 'in it for themselves'. It is this possibility that the present research explores. More particularly, we examine whether, and to what extent, people's narcissism is associated with their endorsement of, and motivation to learn about, leadership theories.

\section{Narcissism and Leadership}

Narcissism is commonly conceptualized as a set of personality traits that are marked by an inflated sense of self-regard associated with arrogance, entitlement, grandiosity, overconfidence, self-absorption, and an excessive need for admiration (Blair et al., 2008;

Campbell \& Campbell, 2009; Rosenthal \& Pittinsky, 2006). Associated with growing interest in the dark side of leadership, in recent years scholars have become increasingly interested in the suggestion that narcissism and leadership sometimes go hand in hand. As a result, they have sought to explore the impact of narcissism — as typically assessed by the Narcissism Personality Inventory (NPI; Raskin \& Hall, 1979) — on a range of organizational behaviors and outcomes (Braun, 2017; Campbell et al., 2011; Rosenthal \& Pittinsky, 2006).

As anticipated, the resulting evidence indicates that narcissism among leaders (across both lower and higher levels of organizational hierarchies) generally predicts a range of negative consequences for individuals, groups, and organizations as a whole. For example, narcissism has been found to be associated with lower levels of organizational citizenship 
behavior (Yildiz \& Öncer, 2012), more counterproductive workplace behaviors (Penney \& Spector, 2002), and greater risk taking and overconfidence (Meisel et al., 2016). In addition, it has been associated with lower supervisor-rated integrity and interpersonal performance (Blair et al., 2008). Similarly, Judge and colleagues (2006) found that narcissism is associated with enhanced ratings of one's own leadership but diminished ratings of one's leadership by others.

Furthermore, narcissism has also been found to predict the behaviors and outcomes of strategic leaders across organizational (Chatterjee \& Pollock, 2017; Reina et al., 2014) and political domains (Deluga, 1997; Hill \& Yousey, 1998). Here researchers have observed that CEO narcissism is not necessarily associated with higher or lower firm performance overall but rather with more fluctuating performance (Chatterjee \& Hambrick, 2007; Wales et al., 2013). At the same time, there is also evidence that CEO narcissism is associated with greater managerial fraud (Rijsenbilt, \& Commandeur, 2013) and higher CEO compensation the longer CEOs stay with an organization (O'Reilly et al., 2014).

These issues have also become increasingly topical in the context of widespread public distrust of leaders in business and politics (e.g., McLean \& Elkind, 2013; Moore, 2009). High-profile corporate scandals (e.g., in Volkswagen (Germany) and the Australian banking industry (e.g., as revealed by the 2017 Royal Banking Commission) together with the collapse of businesses such as Enron and Lehman Brothers (US), the Royal Bank of Scotland (UK), has also drawn attention to the arrogance, incompetence, and narcissism of prominent business leaders (Craig \& Amernic, 2011; Gladwell, 2002; Tourish, 2013). Indeed, such concerns have been seen by some scholars as emblematic of a larger crisis in the field of leadership research, education, and training (Kellerman, 2012; Tourish, 2013). Amongst other things, they have suggested that, like moths to a flame, narcissists may be drawn naturally to positions of power and influence and that, once there, their narcissism will tend 
to be accentuated by the opportunities for self-advancement that high office affords (Brunell et al., 2008; Grijalva et al., 2015; Paunonen et al., 2006).

However, while it is clearly relevant to our present concerns, this literature does not speak directly to the question of whether the science of leadership is in any way related to leader narcissism. More specifically, while it suggests that people who are more narcissistic will tend to find leadership roles appealing, it does not tell us whether, at a more fundamental level, they will also be attracted to the body of theory which explores questions of leadership.

\section{The Origins of Narcissism}

Related to our core question of whether leadership theory appeals to narcissists, it is also possible that the science of leadership might pander to, and perhaps serve to cultivate, narcissism. This is interesting and important because while the focus of most of the research on narcissism and leadership has understandably been on whether leader narcissism has positive or negative consequences, questions about the origins of narcissism in leaders have largely been ignored. This means that if a candidate for leadership presents with high narcissism, this is typically taken as a reflection of a stable disposition or personality trait. Yet, as with personality more generally, we can see narcissism not simply as a fixed input but also partly as an outcome of the unfolding trajectory of a person's interactions within their social world (Haslam et al., 2013; Reynolds et al., 2010; Roberts et al., 2006).

Along these lines, several theorists have speculated that an individual's narcissism and hubris could be increased by the experience of attaining a leadership position and of being treated by others, and coming to see oneself, as superior and 'special' (Campbell \& Campbell, 2011; Kellerman, 2011; Owen, 2006; Owen \& Davidson, 2009; Tourish, 2013). In this vein, Haslam and colleagues (2011) discuss a four-phase "leadership trap" whereby (a) leaders become successful as a result of the collective efforts of the group they have helped to build, but (b) credit and rewards for group success tends to flow to leaders rather than to 
followers, and this in turn (c) feeds the ego and narcissistic tendencies of leaders, in ways that ultimately (d) undermine group success. Similarly, Owen (2006) argues that people in powerful leadership positions (e.g., Heads of government and CEOs of large companies) frequently succumb to a clinical condition that they refer to as "hubris syndrome". Associated with excessive pride and self-confidence, this centers on "a narcissistic propensity to see (the) world primarily as an arena to exercise power and seek glory" (Owen \& Davidson, 2009, p. 1398). Described as a "syndrome of position", this is seen to result from holding substantial power with minimal constraints on one's personal authority over a long period of time (Owen, 2006; see also Brennan \& Conroy, 2013).

Taking this idea further, in the wake of the corporate scandals and failures of recent years, Tourish (2013) has suggested that leadership research, teaching, and training may themselves encourage and promote narcissism in corporate leaders. Indeed, Kellerman (2012) notes that this can lead to a surreal disjuncture whereby major organizations (e.g., the investment bank Goldman Sachs) are applauded for their leadership programs at the same time that they are criticized for their greed and corruption. Along similar lines, Bergman and colleagues (2010) have suggested that management education may increase narcissism in classrooms - a possibility which appears to be supported by evidence that narcissism is higher in business than psychology students, leading to speculation that business schools may inadvertently be teaching their graduates to become more narcissistic via their focus on management and leadership education (Westerman et al., 2012).

\section{The Present Research}

To explore the possibility that leadership theory appeals to (and hence perhaps encourages) narcissism, in the present research we examine the association between individuals' narcissism and their endorsement of leadership theories. In this regard, it is worth noting that many contemporary (traditional and "new-genre") theories of leadership, 
are leader-centric in so far as they focus on the attributes, actions, and qualities of leaders as primary determinants of group success (Bass \& Bass, 2008; Northouse, 2018). Indeed, Tourish (2013) suggests that even though modern theories (e.g., of transformational and charismatic leadership; Bass \& Riggio, 2006) have moved beyond the classical 'great man' theory (after Carlyle, 1840), they continue to reinforce a 'heroic' view of the leader as the principal driver of organizational success. More generally, this emphasis on the importance of leaders (even where this is unwarranted) has been characterized by Meindl and colleagues (1985) as emblematic of 'the romance of leadership' — a romance which leads to the contribution of followers and environmental factors being largely overlooked.

Yet because narcissism is a collection of traits centered around an excessive focus on the self and one's own abilities and influence, it follows that to the extent that leadership theories emphasize an individual's extraordinary capabilities, they may be attractive to narcissists. This is the possibility that the present research explores - seeking to discover whether, and to what extent, leadership theories appeal to narcissists.

To answer this question, we conducted a study in which we assessed individuals' level of narcissism and then examined their endorsement of, and interest in, different types of leadership theory. Given that there are hundreds of theories of leadership that we might have selected for this purpose, we included not one but a range of established theories that differed in the degree to which they focused on the qualities and behaviors of the individual leader. At one end of this continuum, this included theories that focus more or less exclusively on the psychology and behavior of individual leaders (e.g., trait leadership theory; Conger, \& Kanungo, 1987; Gardner \& Avolio, 1998). At the other end were theories that focus much more on the followers that a leader leads (e.g., servant leadership theory; Greenleaf, 1977; Van Dierendonck, 2011). In addition, we also included several control variables that might affect people's endorsement of leadership theories (notably demographic variables, the Big 
Five personality traits, and motivational and ideological variables) to examine the degree to which any association between narcissism and endorsement of leadership theories holds true when controlling for these variables.

\section{Method}

\section{Participants and Design}

To address our research question, we sought to collect data from a total of 250 participants. Our aim was to obtain accurate and reliable estimations of effect sizes (rather than statistically significant estimates of expected effects). Accordingly, this target sample size was determined by the number of participants needed to derive precise estimates of coefficients (which stabilize at a sample size of 250; Schönbrodt \& Perugini, 2013) rather than by the number of participants required for a particular size of effect to be significant at a particular level of statistical significance. Participants were required to hold a leadership position, defined as having formal responsibility for managing and directing the activities of at least two people. For this purpose, an initial sample of 303 respondents recruited through Prolific Academic and completed the survey, while an additional 15 people started but did not complete the survey. A total of 26 were excluded because they stated that they did not hold a leadership position, and 16 were excluded because they did not respond to the control questions as instructed ("Please select 7, 'completely' to the following item 'Jupiter is larger than Earth", and "Please select 1, 'not at all' to the following item 'New Zealand is the largest country in the world'). This resulted in a final sample of 261 participants (114 men, 147 women).

The majority of respondents were citizens of the United Kingdom or the United States ( $n=175$ and $n=37$ ), while the remaining participants were citizens of a European Union member country $(n=31)$, Canada $(n=5)$ and other countries $(n=7)$. Their age ranged from 25 to 66 years $(M=33.88 ; S D=9.47)$ and their work experience ranged from one to 47 years 
$(M=17.10 ; S D=10.14)$. They had been in their current leadership position for between zero and 232 months $(M=26.39 ; S D=30.96)$ and on average they had formal responsibility for 11 people $(S D=22.39)$. The six top industry sectors they were drawn from were education ( $n$ $=41)$, health $(n=31)$, information technology/ telecommunication $(n=26)$, retail $(n=20)$, manufacturing $(n=10)$, and government $(n=9)$. All but 2 participants had completed high school, with 180 obtaining a bachelor's or higher degree, including 67 with postgraduate degrees.

\section{Procedure and Materials}

Participants were invited to respond to a 10-15-minute survey about leadership styles. After providing their informed consent, they responded to several measures (as described in detail below) assessing narcissism, their endorsement of leadership theories, control measures, and demographic questions. The study received ethical approval from the authors' university departmental ethics committee (protocol title 'Narcissism and Leadership Styles'; Ref: 17-PSYCH-PHD-72-JS).

\section{Endorsement of Leadership Theories}

Participants were presented with a short definition and descriptions of 11 established theories of, or approaches to leadership, as recognized in key handbooks and reviews of leadership theories (Bass \& Bass, 2008; Dinh et al. 2014; Northouse, 2018; see Supplementary Materials for detailed descriptions of the theories). These theories were selected to represent a range of different leadership styles or categories including those that Dinh et al. (2014) identified as being prominent in 10 top-tier academic leadership journals from 2000 to 2012, as well as traditional theories of directive and vertical leadership (Bass, 2008). The theories that participants were presented with were: (a) authentic leadership (Avolio \& Gardner, 2005; Walumbwa et al., 2008), (b) trait leadership (Stogdill, 1974; Zaccaro, 2007), (c) charismatic leadership (Conger, \& Kanungo, 1987; Gardner \& Avolio, 
1998), (d) directive leadership (Bass, 2008; Sauer, 2011), (e) identity leadership (Haslam et al., 2011; Steffens et al., 2014), (f) Leader-Member-Exchange (LMX) leadership (Gerstner \& Day, 1997; Graen \& Uhl-Bien, 1995), (g) participative leadership (Huang et al., 2010; Somech, 2005), (h) passive by-exception leadership (DeRue et al., 2011; Hinkin, \& Schriesheim, 2008), (i) servant leadership (Greenleaf, 1977; Van Dierendonck, 2011), (j) shared leadership (D'Innocenzo et al., 2016; Pearce \& Conger, 2003), and (k) vertical leadership (Bass, 2008; Pearce \& Sims, 2002).

By way of example, the description of authentic leadership read as follows:

Authentic leadership suggests that effective leaders are genuine and should exhibit these four qualities: self-awareness (e.g., the leader can list their three greatest weaknesses), internalized moral perspective (i.e. the leader's behavior is guided by their internal moral standards), relationship transparency (e.g., the leader admits their mistakes to others), and balanced processing (e.g. the leader listens closely to the ideas of those that disagree with them).

After reading about each theory, respondents were asked "How much would you endorse this theory as a method/style for effective leadership?” In addition to using responses to this question to assess participants' endorsement of each theory, we created a global measure of leadership theory endorsement by averaging participants' endorsement of the 11 different theories $(\alpha=.68)$.

\section{Learning Motivation for Leadership Theories}

After participants had indicated how much they endorsed each leadership theory, they indicated their motivation to learn about each theory. More specifically, they were asked "If you were taking a leadership training course, how interested would you be in learning more about this theory?" Responses were used to create a global measure of learning motivation ( $\alpha$ $=.79)$. 


\section{Narcissism (NPI-16)}

After responding to these questions about the 11 different leadership theories, participants completed the 16-item Narcissistic Personality Inventory $(\alpha=.93$; NPI-16; Ames et al., 2006), This measure is a short version of the 40-item Narcissistic Personality Inventory validated for non-clinical populations (NPI-40; Raskin \& Terry, 1988). In both the NPI-16 and NPI-40 participants are presented with a series of narcissistic statements (e.g., "I like to be the center of attention"; "I like having authority over people"; "I think I am a special person") each of which is paired with an alternative non-narcissistic statement (e.g., "It makes me uncomfortable to be the center of attention"; "I don't mind following orders"; "I am no better or no worse than most people"). They are then typically forced to choose one of the paired statements. For the sake of brevity and to minimize participant fatigue (see Gentile et al., 2013), in the present study, we included only the narcissistic statements and asked participants to indicate how much each statement applied to them on a 7-point scale from 1 (not at all) to 7 (completely).

\section{Big Five Personality Traits}

Participants completed the 10-item Big Five Inventory (BFI-10; Rammstedt \& John, 2007), which is a validated short measure of the personality traits: extraversion, agreeableness, conscientiousness neuroticism, openness ( $r$ s between .17 and .40 ). A sample item is "I see myself as someone who is outgoing, sociable" (extraversion).

\section{Social Dominance Orientation (SDO)}

We administered the revised 8-item social dominance orientation measure developed by Ho and colleagues (2015; e.g., "An ideal society requires some groups to be on top and others to be on the bottom"; $\alpha=.86$ ). 


\section{Leadership Growth Mindset}

To assess their belief that a person's leadership abilities are either fixed or capable of improvement (growth), participants completed an 8-item leadership growth mindset scale ( $\alpha$ $=.87$ ) adapted from Dweck (2006; e.g., "No matter who you are, you can significantly change your leadership ability").

\section{Demographic Variables}

Finally, participants were asked to indicate their gender, age, level of education, nationality, and to answer questions about their leadership role and experience, and the industry they worked in.

\section{Results}

Means, standard deviations, and bivariate correlations between variables are presented in Table 1 . This shows that narcissism was only weakly correlated or uncorrelated with most demographic and control variables, but was positively associated with the global measures of (a) endorsement of leadership theories and (b) learning motivation for leadership theories.

\section{Narcissism and Endorsement of Leadership Theories}

\section{Endorsement of Leadership Theories}

As can be seen in Table 1, the correlation between narcissism and endorsement of leadership theories was of moderate-to-strong magnitude $r=.43$. In addition, we conducted regression analysis regressing endorsement of leadership theories on narcissism while adding control variables. Results are displayed in Table 2. At Step 1, narcissism (as measured by the NPI-16) was entered as a predictor of endorsement of leadership theories. This indicated that individuals' narcissism was a moderately strong predictor of greater endorsement of leadership theories $(b=.27, \mathrm{SE}=.03, p<.001)$, accounting for $18 \%$ of the total variance. In subsequent steps, various control measures were added including demographic and leadership experience variables (Step 2), the Big Five personality traits (Step 3), and ideological and 
motivational factors (Step 4). In the full model (at Step 4), only education $(b=-.05, \mathrm{SE}=$ $.02, p=.042$ ) was a (negative) predictor (indicating that a higher level of education was associated with weaker endorsement of leadership theories). Furthermore, at all steps (after the inclusion of all control variables), narcissism remained a significant predictor of endorsement of leadership theories $(b=.27, \mathrm{SE}=.04, p<.001)$.

\section{Endorsement of Different Leadership Theories}

In addition, we calculated the correlations between participants' narcissism and their endorsement of each leadership theory. Correlations were represented graphically in a gplot using the $R$ package ggplot2 (Wickham, 2016) using $\mathrm{R}$ open-source software (version 3.3.2; R Core Team, 2016) within the RStudio environment (version 1.2.1578; RStudio Team, 2016). These are displayed in Figure $1 .{ }^{1}$ Point estimations and confidence intervals are presented in Table 3.

Two key patterns emerge from these analyses. First, across the theories, narcissism tended generally to be positively associated with the endorsement of leadership theories. Indeed, none of the observed correlations were negative. Second, there was nevertheless some variability in the relationship between narcissism and leadership theory endorsement such that, as can be seen from Table 3, this correlation ranged from $r=.01$ for participative leadership, $r=.06$ for identity leadership, and $r=.13$ for authentic leadership (at the low

\footnotetext{
${ }^{1}$ Figures 1 and 2 suggest that endorsement or, and learning motivation for, leadership motivations might be particularly pronounced at higher levels of narcissism. We conducted additional analyses to examine this curvilinear trend. This indicated that the squared term of trait narcissism was a positive and statistically significant predictor of both endorsement of $(b=.114, \mathrm{SE}=.028, t=4.09 p<.001)$ and learning motivation for leadership theories $(b=$ $.126, \mathrm{SE}=.038, t=3.33, p=.001)$, indicating that the positive association did indeed increase in strength towards the higher end of the narcissism spectrum.
} 
end), to $r=.28$ for trait leadership, $r=.32$ for leader-member-exchange theory, and $r=.38$ for directive leadership (at the high end).

\section{Narcissism and Motivation to Learn about Leadership Theories}

\section{Motivation to Learn about Leadership Theories}

As Table 1 indicates, the more narcissistic people are, the higher their motivation to learn about leadership theories, $r=.34$. Additionally, we conducted regression analyses, regressing motivation to learn about leadership theories on the NPI-16 narcissism measure, while accounting for the influence of control variables. Again, the NPI-16 score was entered at Step 1, demographic and leadership experience variables at Step 2, Big Five personality measures at Step 3, and ideological and motivational variables are Step 4. Results are shown in Table 4. At Step 1, narcissism predicted learning motivation for leadership theories $(b=$ $.26, \mathrm{SE}=.05, p<.001)$, accounting for a significant $11 \%$ of the total variance. The inclusion of all control variables increased the variance accounted for to $14 \%$ of the total variance but none of the additional variables contributed statistically significantly to the prediction of learning motivation. Again, though, after the inclusion of all control variables, narcissism remained a significant predictor of general learning motivation for the leadership theories $(b$ $=.28, \mathrm{SE}=.06, p<.001)$.

\section{Motivation to Learn about Different Leadership Theories}

In addition, we inspected the correlations between the NPI-16 measure and individuals' inclination to learn more about each leadership theory. Results are summarized in Table 3 and displayed graphically in Figure 2. From this it is can be seen that narcissism tended to be positively associated with interest in learning more about leadership theories and again, none of the observed correlations were negative. At the same time, here too there was some variability in the magnitude of the correlations — varying from those that were weak (for participative leadership, $r=.06$, identity leadership, $r=.10$, and servant leadership, $r=$ 
.10 ) to those that were moderately strong (for trait leadership, $r=.26$, leader-memberexchange, $r=.27$, and directive leadership, $r=.32$ ).

\section{Discussion}

The present research sought to answer a very simple question: whether, and to what extent, narcissism is associated with individuals' endorsement of leadership theories. Our findings suggest that it is, and that this association is of moderate-to-strong magnitude $(r=$ .43 , accounting for $18 \%$ of the total variance in endorsement of leadership theories). Narcissism also remained a significant (and the strongest) predictor of individuals' endorsement of leadership theories after controlling for various demographic, personality, and motivational variables. Similarly, narcissism was also a predictor of individuals' interest in learning about leadership theories ( $r=.34$, accounting for $11 \%$ of the total variance), and this too held true after the inclusion of various control variables.

Inspection of the associations at the level of individual leadership theories indicated that associations were positive in each case (i.e., none of the associations were negative). Nevertheless, there was some variation in the magnitude of the association as a function of the nature of the theory in question. As can be seen from Figures 1 and 2, the associations between narcissism and endorsement of leadership theories were strongest for leadership theories that revolve primarily around the individual leader (e.g., directive, leader-memberexchange, trait, charismatic approaches to leadership). On the other hand, the associations were weaker for group and other-oriented forms of leadership (e.g., participative, identity, authentic, servant approaches to leadership). Nevertheless, it is worth noting that even among this latter cluster of theories, all associations were still positive.

\section{Beyond the End of Leadership Theory}

Where does this leave us? At one level, the present research speaks to previous observations by scholars and commentators that leadership is an activity that all too often 
appeals to, and boosts, people's inflated sense of self. In this regard, the present findings align with previous research which suggests that it is primarily those who have self-serving narcissistic tendencies who have an elevated motivation to lead and exert their influence (Glad, 2002; Sankowsky, 1995; Zhu \& Chen, 2015) and hence are drawn to positions of power and influence (Brunell et al., 2008; Carroll, 1987; Grivalja et al., 2015; Paunonen et al., 2006). In this regard, the present findings accord with these previous suggestions that narcissists desire to be in the center of attention and that one way in which they are able to feed this ambition is by striving for, and ultimately occupying, positions of responsibility and decision power over others.

At the same time, the present research goes beyond previous work by suggesting that the science of leadership — specifically, the theory that researchers have developed — also has appeal to those who are narcissistic.-In this regard, it is relevant that, regardless of variation in their specific form, theories of leadership have one thing in common - namely that they celebrate what makes individuals superior vis-à-vis other individuals and propose that it is this superiority that allows organizations and societies to flourish. According to contemporary leadership theorizing, then, the source of group and organizational success can ultimately be found in some aspect of a leader's 'outstandingness'. This means that other factors — whether they be the group, the social context, or random (e.g., luck) — typically play only a minor (and often no) role in formal scientific analysis (Meindl et al., 1985). Yet one might argue that one of the consequences of shining the theoretical spotlight so brightly on exceptional individuals is that the theorizing this gives rise to inevitably has some degree of narcissistic appeal. Indeed, ironically, this is true even when theorists themselves explicitly challenge problematic individualistic models (as is the case with theories of servant leadership). 
This raises the question of whether it is even possible to develop a science of leadership that curbs these narcissistic tendencies and instead fuels concern for, and contribution to, collective ends. One suggestion that scholars have made repeatedly over the last few decades is that theories need to pay much more attention to followers and to the broader social context in which leaders operate (e.g., Avolio, 2007; Bennis, 1999). Perhaps the time has come to do more than pay lip-service to this suggestion by developing theorizing that sees the psychology and behavior of non-leaders as integral to its scientific analysis and as core to the phenomena to be explained. This seems all the more important when we note that most definitions see followers and other group members as essential to the leadership process - recognizing that, as we noted in the Introduction, this is a process of influencing others in ways that contribute to their willingness to contribute to shared collective (group or organizational) goals (Bennis, 1999; Hollander, 1992; Platow et al., 2015).

Nevertheless, in light of the abundance of leadership theories, the way forward may not necessarily be the development of new theories of leadership and new theories of followership (Uhl-Bien et al., 2014), but instead the generation of integrative analyses of leadership and followership. Indeed, as Hollander (1992) has noted, precisely because leadership is not possible without the enthusiasm and energy of other group members (followers) it is odd that psychological theorizing around leadership has evolved to be independent of, and remote from, psychological theorizing around followership (despite their obvious links; Hollander \& Webb, 1955). That said, it is certainly our sense that the field is changing in this regard — not least through work on followership that sees followers as agents (not just passive respondents to leaders' goals and visions; Uhl-Bien et al., 2014). Nevertheless, this change is slow and it is apparent that leader-centric analyses continue to have broad appeal. 
Concerns and notes of caution of this form are not new. Indeed, over the last 40 or so years leadership scholars have frequently urged caution in the promotion and valorization of leadership once it became apparent that traditional leadership theory and practice did little to either predict or prevent leadership scandals and ethical derailments — and might in some cases have encouraged them (e.g., Gemmill \& Oakley, 1992; Kellerman, 2012). In recent years, this has led to the development of a range of models that seek to counter the potential for ethical derailment. These include, for example, theories of authentic leadership (that have sought to prevent a leader's manipulativeness; Avolio et al., 2004), and servant leadership (that invert standard leadership theory by focusing on a leader's ability to serve others; Van Dierendonck, 2011). Arguably, though, these newer theories have continued to overemphasize and valorize the contribution of the individual leader (and his or her special abilities) over that of the group (Alvesson, \& Einola, 2019; Bennis, 1999). Moreover, as the present data suggest, this means that, at core, these theories still pander to the tastes of the narcissist - it is just that now they aspire to secure high office by being seen to be extraordinarily authentic and more magnanimous than their competitors.

\section{Limitations and Directions for Future Work}

The present research is not without limitations and there are a range of opportunities for future work to expand upon it. First, the study was cross-sectional and this means that we cannot make causal inferences about its findings (Antonakis et al., 2010). Nevertheless, as Spector (2019) points out, cross-sectional designs are an important way to establish that variables are related, and, once this has been established, this opens the door to a range of further questions (does $\mathrm{X}$ cause $\mathrm{Y}$, does $\mathrm{Y}$ cause $\mathrm{X}$, to what extent is this a bi-directional relationship?) that future work might look to unpack using a variety of methodologies and designs. Second, Spector points out that cross-sectional designs are particularly useful when they assess and rule out third variables as potential alternative explanations of relationships. 
In the present work, we sought to rule out a number of alternative explanations of the associations we observed including ones related to demographic factors, leadership experience variables, personality (in form of the BIG-5), SDO, and leadership growth mindset. Clearly, though, there are other variables that it might be worthwhile to examine whether they can account for additional variance. For example, there might be value in examining whether the relationships we have uncovered are bound up with additional variables such as leaders' (demographic and cultural) background, their aspirations, as well as other manifestations' of 'dark psychology' (e.g., hubris syndrome, Owen \& Davidson, 2009; and the dark triad of personality traits, Paulhus \& Williams, 2002).

In addition, it is also noteworthy that there were clearly differences in the narcissistic appeal of particular leadership theories. In this regard, there would be value in examining this patterning more systematically to see whether (and, if so, how and why) people's responsiveness to leadership theories is shaped by the nature and content of those theories. For example, it would be interesting to see whether additional variance can be explained by the extent to which a given theory extols the virtues of the leader vs. followers or is leadercentric vs. other-oriented.

Finally, there are a range of further interesting questions that future programmatic work on the broad topic of the appeal of leadership theory might interrogate. For example, researchers might want to explore how this influenced by (a) variations in the ways in which theories are presented (in more vs. less detail, in lay vs. technical terms) as well as (b) the theories' supposed (conceptual and empirical) validity. It would also be interesting to examine researchers' own motivations for studying leadership as well as the goals they pursue (and their beliefs about the audience they target) when they do. To what extent are they too (or not) seduced by the field's narcissistic allure? 


\section{Concluding Comments}

Leadership is one of the oldest yet still fastest-growing topics of enquiry in psychology and in the social and behavioral sciences more generally. Research output in this field continues to expand, while education and translation efforts have become integral to many (if not most) spheres of activity in society. At the same time, psychological theorizing around leadership has continued to focus on the psychology of the individual as an individual and thereby to lionize the individual leader at the expense of others (particularly followers, the group, and the context they find themselves in). In the present research we explored the possibility that the science of leadership that this has given rise to is especially appealing to those who have a narcissistic concern for self-promotion and self-aggrandizement. Consistent with this proposition, the present results show that the more narcissistic individuals are, the more they endorse various theories of leadership and the more they want to learn about them. This in turn suggests that what motivates people to engage with leadership theory is more a personal concern for the self than a social concern for the greater good.

In the context of historically low levels of public trust in corporate and political leaders, this is an arresting finding. For it suggests that rather than leadership training and theory being the solution to our current woes, it may actually be their cause. Certainly, if the people who are drawn to the study of leadership are primarily interested in looking after themselves, we should not be surprised if they use their learning to do precisely this. Rather too than complain about the narcissism of leaders we should perhaps attend to the narcissism of our own theorizing. After all, if leadership is the drug of choice for narcissists then it is we who are the suppliers. 


\section{References}

Alvesson, M., \& Einola, K. (2019). Warning for excessive positivity: Authentic leadership and other traps in leadership studies. The Leadership Quarterly, 4, 283-395.

Alvesson, M., Bloom, M, \& Sveningsson, S. (2017). Reflexive Leadership: Organising in an Imperfect World. Thousand Oaks: Sage.

Ames, D. R., Rose, P., \& Anderson, C. P. (2006). The NPI-16 as a short measure of narcissism. Journal of Research in Personality, 40, 440-450.

Antonakis, J., Bendahan, S., Jacquart, P., \& Lalive, R. (2010). On making causal claims: A review and recommendations. The Leadership Quarterly, 21, 1086-1120.

Avolio, B. J. (2007). Promoting more integrative strategies for leadership theory-building. American Psychologist, 62, 25-33.

Avolio, B. J., Gardner, W. L., Walumbwa, F. O., Luthans, F., \& May, D. R. (2004). Unlocking the mask: A look at the process by which authentic leaders impact follower attitudes and behaviors. The Leadership Quarterly, 15, 801-823.

Avolio, B. J., \& Gardner, W. L. (2005). Authentic leadership development: Getting to the root of positive forms of leadership. The Leadership Quarterly, 16, 315-338.

Bass, B. M. \& Bass, R. R. (2008). The Bass handbook of leadership: Theory, research, and managerial applications ( $4^{\text {th }}$ ed.). New York US: Free Press.

Bass, B. M., \& Riggio, R. E. (2006). Transformational leadership (2nd ed.). Mahwah, NJ US: Lawrence Erlbaum Associates Publishers.

Bennis, W. (1999). The end of leadership: Exemplary leadership is impossible without full inclusion, initiatives, and cooperation of followers. Organizational Dynamics, 28, 7180

Bergman, J. Z., Westerman, J. W., \& Daly, J. P. (2010). Narcissism in management education. Academy of Management Learning \& Education, 9, 119-131. 
Blair, C. A., Hoffman, B. J., \& Helland, K. R. (2008). Narcissism in organizations: A multisource appraisal reflects different perspectives. Human Performance, 21, 254276.

Braun, S. (2017). Leader narcissism and outcomes in organizations: a review at multiple levels of analysis and implications for future research. Frontiers in Psychology, 8, 773.

Brennan, N. M., \& Conroy, J. P. (2013). Executive hubris: The case of a bank CEO. Accounting, Auditing \& Accountability Journal, 26, 172-195.

Brunell, A. B., Gentry, W. A., Campbell, W. K., Hoffman, B. J., Kuhnert, K. W., \& DeMarree, K. G. (2008). Leader emergence: The case of the narcissistic leader. Personality and Social Psychology Bulletin, 34, 1663-1676.

Campbell, W. K., \& Campbell, S. M. (2009). On the self-regulatory dynamics created by the peculiar benefits and costs of narcissism: A contextual reinforcement model and examination of leadership. Self and Identity, 8, 214-232.

Campbell, W. K., Hoffman, B. J., Campbell, S. M., \& Marchisio, G. (2011). Narcissism in organizational contexts. Human Resource Management Review, 21, 268-284.

Carlyle, T. (1840). Heroes and hero worship. London: Harrap.

Carroll, L. (1987). A study of narcissism, affiliation, intimacy, and power motives among students in business administration. Psychological Reports, 61, 355-358.

Chatterjee, A., \& Hambrick, D. C. (2007). It's all about me: Narcissistic chief executive officers and their effects on company strategy and performance. Administrative Science Quarterly, 52, 351-386.

Chatterjee, A., \& Pollock, T. G. (2017). Master of puppets: How narcissistic CEOs construct their professional worlds. Academy of Management Review, 42(4), 703-725. 
Ciulla, J.B. (1995). Leadership ethics: Mapping the territory. Business Ethics Quarterly 5, 525.

Ciulla, J. B. (2005). The state of leadership ethics and the work that lies before us. Business Ethics: A European Review, 14(4), 323-335.

Conger, J. A. (1990). The dark side of leadership. Organizational Dynamics, 19, 44-55.

Conger, J. A., \& Kanungo, R. N. (1987). Toward a behavioral theory of charismatic leadership in organizational settings. Academy of Management Review, 12, 637-647.

Craig, R., \& Amernic, J. (2011). Detecting linguistic traces of destructive narcissism at-adistance in a CEO's letter to shareholders. Journal of Business Ethics, 101, 563-575.

Dinh, J. E., Lord, R. G., Gardner, W. L., Meuser, J. D., Liden, R. C., \& Hu, J. (2014). Leadership theory and research in the new millennium: Cur- rent theoretical trends and changing perspectives. The Leadership Quarterly, 25, 36-62.

DeRue, D. S., Nahrgang, J. D., Wellman, N. E. D., \& Humphrey, S. E. (2011). Trait and behavioral theories of leadership: An integration and meta-analytic test of their relative validity. Personnel Psychology, 64, 7-52.

D’Innocenzo, L., Mathieu, J. E., \& Kukenberger, M. R. (2016). A meta-analysis of different forms of shared leadership-team performance relations. Journal of Management, 42, 1964-1991.

Deluga, R. J. (1997). Relationship among American presidential charismatic leadership, narcissism, and rated performance. The Leadership Quarterly, 8, 49-65.

Dweck, C. S. (2006). Mindset: The new psychology of success. New York, NY: Random House.

Gabaix, X., \& Landier, A. (2008). Why has CEO pay increased so much? The Quarterly Journal of Economics, 123, 49-100. 
Gardner, W. L., \& Avolio, B. J. (1998). The charismatic relationship: A dramaturgical perspective. Academy of Management Review, 23, 32-58.

Gerstner, C. R., \& Day, D. V. (1997). Meta-Analytic review of leader-member exchange theory: Correlates and construct issues. Journal of Applied Psychology, 82, 827-844.

Gemmill, G., \& Oakley, J. (1992). Leadership: An alienating social myth? Human Relations, $45,113-129$.

Gentile, B., Miller, J. D., Hoffman, B. J., Reidy, D. E., Zeichner, A., \& Campbell, W. K. (2013). A test of two brief measures of grandiose narcissism: The Narcissistic Personality Inventory-13 and the Narcissistic Personality Inventory-16. Psychological Assessment, 25, 1120-1136.

Gladwell, M. (2002). The talent myth. The New Yorker, 22, 28-33.

Glad, B. (2002). Why tyrants go too far: Malignant narcissism and absolute power. Political Psychology, 23, 1-2.

Graen, G. B., \& Uhl-Bien, M. (1995). Relationship-based approach to leadership: Development of leader-member exchange (LMX) theory of leadership over 25 years: Applying a multi-level multi-domain perspective. The Leadership Quarterly, 6, 219247.

Greenleaf, R. K. (1977). Servant leadership: A journey into the nature of legitimate power and greatness. New York: Paulist Press.

Grijalva, E., Harms, P. D., Newman, D. A., Gaddis, B. H., \& Fraley, R. C. (2015). Narcissism and leadership: A meta-analytic review of linear and nonlinear relationships. Personnel Psychology, 68, 1-47.

Haslam, S. A. (2004). Psychology in organizations: The social identity approach (2 $2^{\text {nd }}$ ed.). Sage. 
Haslam, S. A., Jetten, J., Reynolds, K. J., \& Reicher, S. D. (2013). The dangers of isolating the individual: The need for a dynamic and socially structured model of personality. Health Psychology Review, 7, S79-S84.

Haslam, S., Reicher, S., \& Platow, M. (2011). The new psychology of leadership: Identity, influence, and power. London and New York: Psychology Press.

Haslam, S. A., Reicher, S. D., \& Van Bavel, J. J. (2019). Rethinking the nature of cruelty: The role of identity leadership in the Stanford Prison Experiment. American Psychologist, 74, 809-822.

Hill, R. W., \& Yousey, G. P. (1998). Adaptive and maladaptive narcissism among university faculty, clergy, politicians, and librarians. Current Psychology, 17, 163-169.

Hinkin, T. R., \& Schriesheim, C. A. (2008). An examination of "nonleadership": From laissez-faire leadership to leader reward omission and punishment omission. Journal of Applied Psychology, 93, 1234-1248.

Ho, A. K., Sidanius, J., Kteily, N., Sheehy-Skeffington, J., Pratto, F., Henkel, K. E., ... \& Stewart, A. L. (2015). The nature of social dominance orientation: Theorizing and measuring preferences for intergroup inequality using the new $\mathrm{SDO}_{7}$ scale. Journal of Personality and Social Psychology, 109, 1003-1028.

Hollander, E. P. (1985). Leadership and power. In G. Lindzey \& E. Aronson (Eds.), The handbook of social psychology: Vol. II . (pp. 485-537). New York: Random House.

Hollander, E. P. (1992). The essential interdependence of leadership and followership. Current Directions in Psychological Science, 1, 71-75.

Hollander, E. P., \& Webb, W. B. (1955). Leadership, followership, and friendship: an analysis of peer nominations. The Journal of Abnormal and Social Psychology, 50, 163-167. 
House, R., Javidan, M., \& Dorfman, P. (2001). Project GLOBE: An introduction. Applied Psychology, 50, 489-505.

Huang, X., Iun, J., Liu, A., \& Gong, Y. (2010). Does participative leadership enhance work performance by inducing empowerment or trust? The differential effects on managerial and non-managerial subordinates. Journal of Organizational Behavior, 31, 122-143.

Judge, T. A., LePine, J. A., \& Rich, B. L. (2006). Loving yourself abundantly: relationship of the narcissistic personality to self-and other perceptions of workplace deviance, leadership, and task and contextual performance. Journal of Applied Psychology, 91, $762-776$.

Kellerman, B. (2012). The End of Leadership. New York: Harper Business.

Khoo, H. S., \& Burch, G. S. J. (2008). The 'dark side' of leadership personality and transformational leadership: An exploratory study. Personality and Individual Differences, 44, 86-97.

Lord, R. G., Day, D. V., Zaccaro, S. J., Avolio, B. J., \& Eagly, A. H. (2017). Leadership in applied psychology: Three waves of theory and research. Journal of Applied Psychology, 102, 434-451.

McGill, M. E., \& Slocum Jr, J. W. (1998). A little leadership, please? Organizational Dynamics, 26, 39-50.

McLean, B., \& Elkind, P. (2013). The smartest guys in the room: The amazing rise and scandalous fall of Enron. New York US: Penguin.

Meindl, J. R., Ehrlich, S. B., \& Dukerich, J. M. (1985). The romance of leadership. Administrative Science Quarterly, 30, 78-102. 
Meisel, M. K., Ning, H., Campbell, W. K., \& Goodie, A. S. (2016). Narcissism, overconfidence, and risk taking in US and Chinese student samples. Journal of CrossCultural Psychology, 47, 385-400.

Moore, M. (2009). Capitalism: A love story [motion picture]. United States: Dog Eat Dog Films.

Northouse, P. G. (2018). Introduction to leadership: Concepts and practice (4 ${ }^{\text {th }}$ ed.). Thousand Oaks: Sage Publications.

O'Reilly III, C. A., Doerr, B., Caldwell, D. F., \& Chatman, J. A. (2014). Narcissistic CEOs and executive compensation. The Leadership Quarterly, 25, 218-231.

Owen, L. D. (2006). Hubris and nemesis in heads of government. Journal of the Royal Society of Medicine, 99, 548-551.

Owen, D., \& Davidson, J. (2009). Hubris syndrome: An acquired personality disorder? A study of US Presidents and UK Prime Ministers over the last 100 years. Brain, 132, 1396-1406.

Paulhus, D. L., \& Williams, K. M. (2002). The dark triad of personality: Narcissism, Machiavellianism, and psychopathy. Journal of Research in Personality, 36, 556-563.

Paunonen, S. V., Lönnqvist, J. E., Verkasalo, M., Leikas, S., \& Nissinen, V. (2006). Narcissism and emergent leadership in military cadets. The Leadership Quarterly, 17, 475-486.

Pearce, C. L., \& Conger, J. A. (eds.) (2003). Shared leadership: Reframing the hows and whys of leadership. Thousand Oaks: Sage Publications.

Pearce, C. L., \& Sims Jr, H. P. (2002). Vertical versus shared leadership as predictors of the effectiveness of change management teams: An examination of aversive, directive, transactional, transformational, and empowering leader behaviors. Group Dynamics: Theory, Research, and Practice, 6, 172-197. 
Penney, L. M., \& Spector, P. E. (2002). Narcissism and counterproductive work behavior: Do bigger egos mean bigger problems? International Journal of Selection and Assessment, 10, 126-134.

Platow, M. J., Haslam, S. A., Reicher, S. D., \& Steffens, N. K. (2015). There is no leadership if no-one follows: Why leadership is necessarily a group process. International Coaching Psychology Review, 10, 20-37.

R Core Team (2016). R: A language and environment for statistical computing (Version 3.3.2). Vienna, Austria, R: Foundation for Statistical Computing.

Rammstedt, B., \& John, O. P. (2007). Measuring personality in one minute or less: A 10-item short version of the Big Five Inventory in English and German. Journal of Research in Personality, 41, 203-212.

Raskin, R. N., \& Hall, C. S. (1979). A narcissistic personality inventory. Psychological Reports, 45, 590 .

Raskin, R., \& Terry, H. (1988). A principal-components analysis of the Narcissistic Personality Inventory and further evidence of its construct validity. Journal of Personality and Social Psychology, 54, 890-902.

Reina, C. S., Zhang, Z., \& Peterson, S. J. (2014). CEO grandiose narcissism and firm performance: The role of organizational identification. The Leadership Quarterly, 25, 958-971.

Reynolds, K. J., Turner, J. C., Branscombe, N. R., Mavor, K. I., Bizumic, B., \& Subašić, E. (2010). Interactionism in personality and social psychology: An integrated approach to understanding the mind and behaviour. European Journal of Personality, 24, 458482.

Rijsenbilt, A., \& Commandeur, H. (2013). Narcissus enters the courtroom: CEO narcissism and fraud. Journal of Business Ethics, 117, 413-429. 
Roberts, B. W., Walton, K. E., \& Viechtbauer, W. (2006). Patterns of mean-level change in personality traits across the life course: A meta-analysis of longitudinal studies. Psychological Bulletin, 132, 1-25.

Rosenthal, S. A., \& Pittinsky, T. L. (2006). Narcissistic leadership. The Leadership Quarterly, 17, 617-633.

Rost, J. C. (2008). Leadership definition. In A. Marturano \& J. Gosling (Eds.), Leadership: The key concepts (pp. 94-99). New York, NY: Routledge.

RStudio Team (2016). RStudio: Integrated Development for R. RStudio, Inc. (Version 1.0.136). Boston, MA.

Sankowsky, D. (1995). The charismatic leader as narcissist: Understanding the abuse of power. Organizational Dynamics, 23, 57-71.

Sauer, S. J. (2011). Taking the reins: The effects of new leader status and leadership style on team performance. Journal of Applied Psychology, 96, 574-587.

Schönbrodt, F. D., \& Perugini, M. (2013). At what sample size do correlations stabilize? Journal of Research in Personality, 47, 609-612.

Smith, P. M. (1995). Leadership. In A. S. R. Manstead \& M. R. C. Hewstone (Eds.), The Blackwell dictionary of social psychology (pp. 358-362). Oxford, UK: Blackwell.

Somech, A. (2005). Directive versus participative leadership: Two complementary approaches to managing school effectiveness. Educational Administration Quarterly, 41, 777-800.

Spector, P. E. (2019). Do not cross me: Optimizing the use of cross-sectional designs. Journal of Business and Psychology, 34, 125-137.

Steffens, N. K., Haslam, S. A., Reicher, S. D., Platow, M. J., Fransen, K., Yang, J., Ryan, M. K., Jetten, J., Peters, K., \& Boen, F. (2014). Leadership as social identity management: Introducing the Identity Leadership 
Inventory (ILI) to assess and validate a four-dimensional model. The Leadership Quarterly, 25, 1001-1024.

Stogdill, R.M. (1974). Handbook of leadership: A survey of the literature. New York, NY: Free Press.

Tourish, D. (2013). The dark side of transformational leadership: A critical perspective. London \& New York: Routledge.

Uhl-Bien, M., Riggio, R. E., Lowe, K. B., \& Carsten, M. K. (2014). Followership theory: A review and research agenda. The Leadership Quarterly, 25, 83-104.

Van Dierendonck, D. (2011). Servant leadership: A review and synthesis. Journal of Management, 37, 1228-1261.

Wales, W. J., Patel, P. C., \& Lumpkin, G. T. (2013). In pursuit of greatness: CEO narcissism, entrepreneurial orientation, and firm performance variance. Journal of Management Studies, 50, 1041-1069.

Walumbwa, F. O., Avolio, B. J., Gardner, W. L., Wernsing, T. S., \& Peterson, S. J. (2008). Authentic leadership: Development and validation of a theory-based measure. Journal of Management, 34, 89-126.

Westerman, J. W., Bergman, J. Z., Bergman, S. M., \& Daly, J. P. (2012). Are universities creating millennial narcissistic employees? An empirical examination of narcissism in business students and its implications. Journal of Management Education, 36, 5-32.

Wickham, H. (2016). ggplot2: Elegant graphics for data analysis. Springer: New York.

Yildiz, M. L., \& Öncer, A. Z. (2012). Narcissism as a moderator of the relationship between organizational trust and organizational citizenship behaviour. International Journal of Business and Social Science, 3, 212-222.

Zaccaro, S. J. (2007). Trait-based perspectives of leadership. American Psychologist, 62, 616. 
Zhu, D. H., \& Chen, G. (2015). CEO narcissism and the impact of prior board experience on corporate strategy. Administrative Science Quarterly, 60, 31-65. 


\section{Tables and Figures}

Table 1. Means, standard deviations, and bivariate correlations between variables.

\begin{tabular}{|c|c|c|c|c|c|c|c|c|c|c|c|c|c|c|c|c|c|c|c|c|}
\hline Variable & Mean & $S D$ & 1 & 2 & 3 & 4 & 5 & 6 & 7 & 8 & 9 & 10 & 11 & 12 & 13 & 14 & 15 & 16 & 17 & 18 \\
\hline 1. Narcissism (NPI-16) ${ }^{a}$ & 3.93 & 1.10 & - & & & & & & & & & & & & & & & & & \\
\hline 2. Endorsement lead. theories ${ }^{a}$ & 4.87 & 0.68 & .43 & - & & & & & & & & & & & & & & & & \\
\hline 3. Learning motivation lead. theories ${ }^{a}$ & 4.95 & 0.86 & .34 & .69 & - & & & & & & & & & & & & & & & \\
\hline 4. Age & 38.88 & 9.47 & -.05 & -.04 & -.04 & - & & & & & & & & & & & & & & \\
\hline 5. Gender & 0.56 & 0.50 & -.15 & -.08 & .00 & .06 & - & & & & & & & & & & & & & \\
\hline 6. Level of education & 5.66 & 1.65 & .03 & -.13 & -.11 & -.02 & -.07 & - & & & & & & & & & & & & \\
\hline 7. Nationality dummy UK & 0.67 & 0.47 & -.23 & -.05 & .00 & .17 & .30 & -.23 & - & & & & & & & & & & & \\
\hline 8. Nationality dummy US & 0.14 & 0.35 & .09 & .00 & -.02 & -.09 & -.24 & .10 & -.58 & - & & & & & & & & & & \\
\hline 9. Nationality dummy EU & 0.12 & 0.32 & .16 & .12 & .04 & -.10 & -.11 & .11 & -.52 & -.15 & - & & & & & & & & & \\
\hline 10. Tenure in leadership role ${ }^{b}$ & 26.39 & 30.96 & -.01 & -.08 & .00 & .26 & .10 & -.03 & .07 & .01 & -.09 & - & & & & & & & & \\
\hline 11. Leadership responsibility ${ }^{c}$ & 10.55 & 22.39 & .19 & .15 & .14 & .02 & -.03 & .08 & -.03 & .09 & -.02 & .08 & - & & & & & & & \\
\hline 12. Extraversion ${ }^{\mathrm{d}}$ & 3.21 & 0.92 & .38 & .14 & .17 & .14 & .12 & -.05 & .06 & -.06 & .06 & -.03 & .05 & - & & & & & & \\
\hline 13. Agreeableness ${ }^{d}$ & 3.46 & 0.78 & -.11 & .06 & .09 & -.08 & -.04 & -.18 & -.05 & .04 & .04 & -.09 & -.04 & .03 & - & & & & & \\
\hline 14. Conscientiousness ${ }^{\mathrm{d}}$ & 3.91 & 0.81 & .15 & .04 & .08 & .11 & .11 & -.07 & .08 & -.06 & -.08 & .14 & .11 & .19 & .14 & - & & & & \\
\hline 15. Neuroticism ${ }^{d}$ & 2.82 & 0.94 & -.25 & -.16 & -.12 & -.05 & .22 & .11 & .09 & -.11 & .02 & .03 & -.03 & -.28 & -.22 & -.17 & - & & & \\
\hline 16. Openness ${ }^{\mathrm{d}}$ & 3.57 & 0.85 & -.01 & -.01 & -.03 & .04 & -.05 & .09 & .02 & .07 & -.07 & -.03 & -.12 & -.07 & .02 & .01 & .09 & - & & \\
\hline 17. $\mathrm{SDO}^{\mathrm{a}}$ & 3.00 & 1.19 & .27 & .11 & .05 & -.01 & -.12 & -.09 & .05 & -.09 & -.06 & .00 & .03 & .07 & -.14 & -.04 & -.01 & -.19 & - & \\
\hline 18. Leadership growth mindset ${ }^{a}$ & 4.80 & 1.10 & -.08 & -.12 & .05 & -.07 & -.07 & .06 & .07 & -.01 & -.15 & -.12 & .02 & .02 & .14 & .12 & -.15 & .07 & -.17 & - \\
\hline
\end{tabular}

Note. $N=261$. Endorsement lead. theories = Endorsement of leadership theories; Learning motivation lead. theories = Learning motivation for leadership theories;

Nationality dummy UK = dummy variable for United Kingdom (coded $1=$ UK and $0=$ other), dummy US $=$ dummy variable for United States (coded $1=$ and $0=$ other), dummy EU = dummy variable for EU member country (coded $1=\mathrm{EU}$ and $0=$ other); SDO = Social Dominance Orientation; ${ }^{\mathrm{a}}$ Ratings on scales ranging from 1 ( $n$ ot at all) to 7 (completely); ${ }^{\mathrm{b}}$ Tenure in leadership role $=$ months spent in leadership role; ${ }^{\mathrm{c}}$ Leadership responsibility $=$ number of subordinates that leader has responsibility for;

${ }^{\mathrm{d}}$ Ratings on scales ranging from 1 (not at all) to 5 (completely).

$r \mathrm{~s} \geq|.12|=p<.05, r \mathrm{~s} \geq|.21|=p<.001$. 
Table 2. Hierarchical linear regression results for the association between narcissism and endorsement of leadership theories (including sensitivity analyses adding various control variables).

\begin{tabular}{|c|c|c|c|c|c|c|c|c|c|c|c|c|}
\hline \multirow[b]{2}{*}{ Variable } & \multicolumn{3}{|c|}{ Step 1} & \multicolumn{3}{|c|}{ Step 2} & \multicolumn{3}{|c|}{ Step 3} & \multicolumn{3}{|c|}{ Step 4} \\
\hline & $b$ & $S E$ & $t$ & $b$ & $S E$ & $t$ & $b$ & $S E$ & $t$ & $b$ & $S E$ & $t$ \\
\hline Narcissism & .27 & .03 & $7.62^{* *}$ & .25 & .04 & $7.01^{* *}$ & .27 & .04 & $6.59^{* *}$ & .27 & .04 & $6.22^{* * *}$ \\
\hline$\Delta R^{2}$ & & & .18 & & & & & & & & & \\
\hline$R^{2}$ & & & .18 & & & & & & & & & \\
\hline Age & & & & .00 & .00 & 0.18 & .00 & .00 & 0.02 & .00 & .00 & 0.12 \\
\hline Gender & & & & -.03 & .08 & 0.37 & .00 & .08 & 0.06 & -.01 & .09 & 0.11 \\
\hline Education & & & & -.06 & .02 & $2.52^{*}$ & -.05 & .02 & $2.19^{*}$ & -.05 & .02 & $2.04^{*}$ \\
\hline Nationality dummy UK & & & & .23 & .16 & 1.48 & .25 & .16 & 1.57 & .23 & .16 & 1.49 \\
\hline Nationality dummy US & & & & .15 & .18 & 0.88 & .15 & .18 & 0.83 & .12 & .18 & 0.65 \\
\hline Nationality dummy EU & & & & .33 & .18 & 1.82 & .34 & .18 & 1.83 & .28 & .19 & 1.52 \\
\hline Tenure leader role & & & & -.01 & .00 & 1.31 & -.01 & .00 & 1.20 & -.01 & .00 & 1.37 \\
\hline Leadership responsibility & & & & .01 & .00 & 1.61 & .01 & .00 & 1.65 & .01 & .00 & 1.72 \\
\hline$\Delta R^{2}$ & & & & & & .05 & & & & & & \\
\hline$R^{2}$ & & & & & & .23 & & & & & & \\
\hline Extraversion & & & & & & & -.05 & .05 & 0.95 & -.04 & .05 & 0.89 \\
\hline Agreeableness & & & & & & & .06 & .05 & 1.08 & .07 & .05 & 1.23 \\
\hline Conscientiousness & & & & & & & -.03 & .05 & 0.67 & -.03 & .05 & 0.50 \\
\hline Neuroticism & & & & & & & -.04 & .05 & 0.82 & -.05 & .05 & 0.99 \\
\hline Openness & & & & & & & .01 & .05 & 0.22 & .01 & .05 & 0.80 \\
\hline$\Delta R^{2}$ & & & & & & & & & .01 & & & \\
\hline$R^{2}$ & & & & & & & & & .24 & & & \\
\hline SDO & & & & & & & & & & -.01 & .04 & 0.26 \\
\hline Leadership growth mindset & & & & & & & & & & -.06 & .04 & 1.64 \\
\hline$\Delta R^{2}$ & & & & & & & & & & & & .01 \\
\hline$R^{2}$ & & & & & & & & & & & & .25 \\
\hline
\end{tabular}

Note. Nationality dummy UK $=$ dummy variable for United Kingdom (coded $1=\mathrm{UK}$ and $0=$ other), dummy US = dummy variable for United States ( $\operatorname{coded} 1=$ and $0=$ other), dummy EU $=$ dummy variable for EU member country (coded $1=\mathrm{EU}$ and $0=$ other); $\mathrm{SDO}=$ Social Dominance Orientation; ${ }^{*} p<.05 .{ }^{* *} p<.001$. 
Table 3. Associations between narcissism (NPI-16) and endorsement of, and learning motivation for, different leadership theories.

\begin{tabular}{lc}
\hline \multicolumn{1}{c}{ Variable } & $r[\mathrm{CIs}]$ \\
\hline \multicolumn{1}{c}{ Endorsement of Different Leadership Theories } & \\
\hline Participative Leadership & $.01[-.11, .13]$ \\
Identity Leadership & $.06[-.06, .18]$ \\
Authentic Leadership & $.13[.01, .25]$ \\
Servant Leadership & $.15[.03, .27]$ \\
Shared Leadership & $.16[.04, .28]$ \\
Vertical Leadership & $.23[.11, .34]$ \\
Charismatic Leadership & $.24[.12, .35]$ \\
Passive Leadership & $.26[.14, .37]$ \\
Trait Leadership & $.28[.17, .39]$ \\
Leader-Member-Exchange & $.32[.21, .43]$ \\
Directive Leadership & $.38[.28, .48]$ \\
\hline \multicolumn{1}{c}{ Learning Motivation for Different Leadership Theories } & \\
\hline Participative Leadership & $.06[-.06, .18]$ \\
Identity Leadership & $.10[-.03, .22]$ \\
Servant Leadership & $.10[-.03, .22]$ \\
Shared Leadership & $.12[.00, .24]$ \\
Authentic Leadership & $.15[.03, .27]$ \\
Vertical Leadership & $.22[.10, .33]$ \\
Passive Leadership & $.23[.11, .34]$ \\
Charismatic Leadership & $.25[.14, .36]$ \\
Trait Leadership & $.26[.14, .37]$ \\
Leader-Member-Exchange & $.27[.16, .38]$ \\
Directive Leadership & $.32[.21, .42]$ \\
\hline
\end{tabular}

Note. $N=261$. NPI-16 $=16$-item Narcissistic Personality Inventory. 
Table 4. Hierarchical linear regression results for the association between narcissism and learning motivation for leadership theories (including sensitivity analyses adding various control variables).

\begin{tabular}{|c|c|c|c|c|c|c|c|c|c|c|c|c|}
\hline & \multicolumn{3}{|c|}{ Step 1} & \multicolumn{3}{|c|}{ Step 2} & \multicolumn{3}{|c|}{ Step 3} & \multicolumn{3}{|c|}{ Step 4} \\
\hline & $b$ & $S E$ & $t$ & $b$ & $S E$ & $t$ & $b$ & $S E$ & $t$ & $b$ & $S E$ & $t$ \\
\hline Narcissism & .26 & .05 & $5.74^{* *}$ & .26 & .05 & $5.35^{* * *}$ & .27 & .06 & $4.81^{\text {*** }}$ & .28 & .06 & $4.87^{\text {*** }}$ \\
\hline$\Delta R^{2}$ & & & .11 & & & & & & & & & \\
\hline$R^{2}$ & & & .11 & & & & & & & & & \\
\hline Age & & & & .00 & .01 & 0.66 & .00 & .01 & 0.59 & .00 & .01 & 0.50 \\
\hline Gender & & & & .05 & .11 & 0.50 & .06 & .11 & 0.51 & .06 & .12 & 0.50 \\
\hline Education & & & & -.06 & .03 & 1.80 & -.04 & .03 & 1.36 & -.05 & .03 & 1.50 \\
\hline Nationality dummy UK & & & & .15 & .21 & 0.72 & .15 & .21 & 0.72 & .16 & .21 & 0.74 \\
\hline Nationality dummy US & & & & .03 & .24 & 0.14 & .02 & .24 & 0.07 & .02 & .24 & 0.09 \\
\hline Nationality dummy EU & & & & .11 & .24 & 0.47 & .09 & .25 & 0.35 & .11 & .25 & 0.42 \\
\hline Tenure leader role & & & & .00 & .00 & 0.05 & .00 & .00 & 0.22 & .00 & .00 & 0.34 \\
\hline Leadership responsibility & & & & .01 & .00 & 1.55 & .01 & .00 & 1.51 & .01 & .00 & 1.44 \\
\hline$\Delta R^{2}$ & & & & & & .03 & & & & & & \\
\hline$R^{2}$ & & & & & & .14 & & & & & & \\
\hline Extraversion & & & & & & & .02 & .06 & 0.28 & .02 & .06 & 0.24 \\
\hline Agreeableness & & & & & & & .12 & .07 & 1.75 & .11 & .07 & 1.58 \\
\hline Conscientiousness & & & & & & & -.01 & .07 & 0.21 & -.02 & .07 & 0.36 \\
\hline Neuroticism & & & & & & & -.01 & .06 & 0.11 & .00 & .06 & 0.07 \\
\hline Openness & & & & & & & -.01 & .06 & 0.14 & -.02 & .06 & 0.33 \\
\hline$\Delta R^{2}$ & & & & & & & & & .01 & & & \\
\hline$R^{2}$ & & & & & & & & & .15 & & & \\
\hline SDO & & & & & & & & & & -.03 & .05 & 0.54 \\
\hline Leadership growth mindset & & & & & & & & & & .05 & .05 & 1.05 \\
\hline$\Delta R^{2}$ & & & & & & & & & & & & .01 \\
\hline$R^{2}$ & & & & & & & & & & & & .16 \\
\hline
\end{tabular}

Note. Nationality dummy UK $=$ dummy variable for United Kingdom (coded $1=\mathrm{UK}$ and $0=$ other), dummy US = dummy variable for United States ( $\operatorname{coded} 1=$ and $0=$ other), dummy EU $=$ dummy variable for EU member country (coded $1=\mathrm{EU}$ and $0=$ other); SDO $=$ Social Dominance Orientation. ${ }^{*} p<.05 .{ }^{* *} p<.001$. 


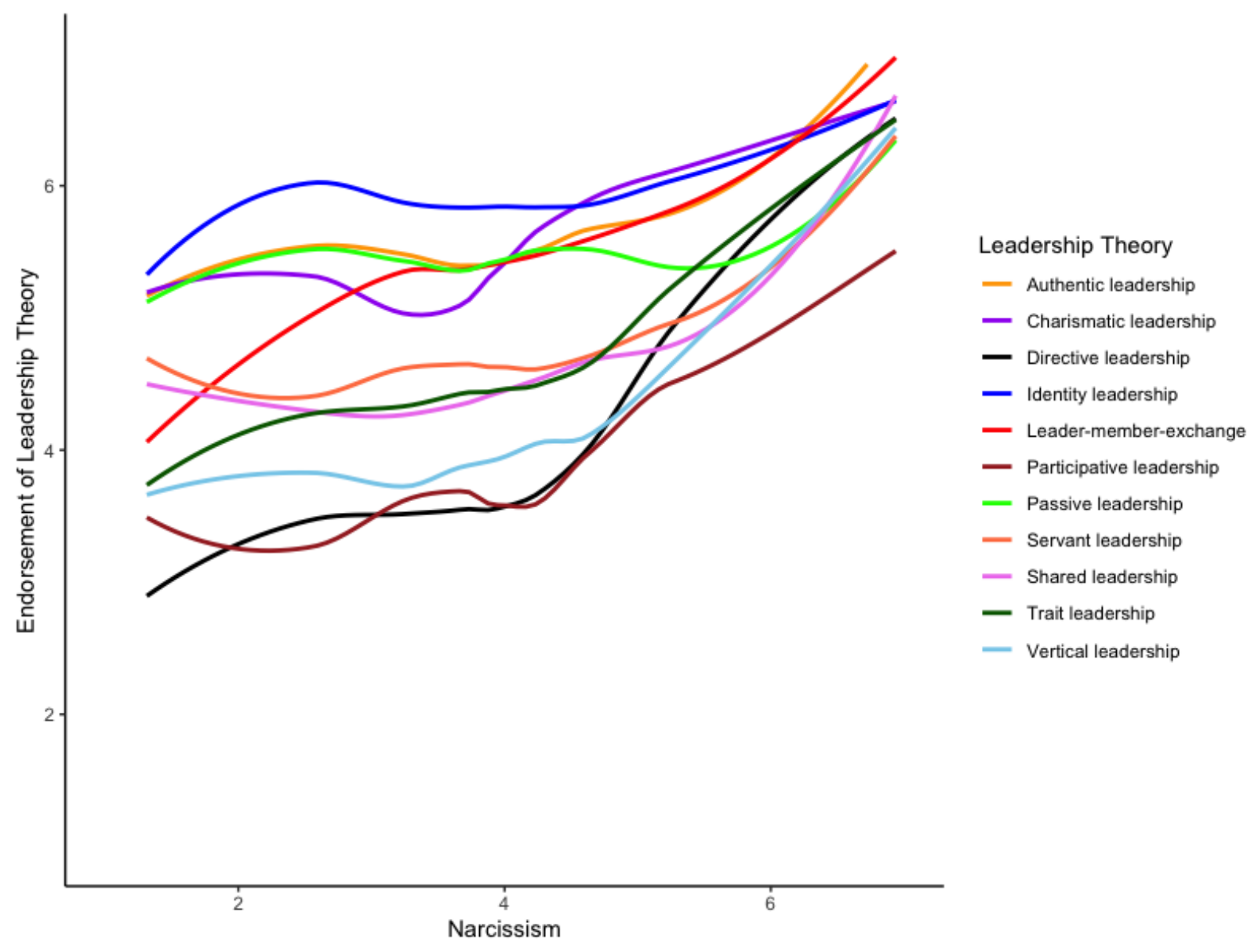

Figure 1. Associations between narcissism (NPI-16) and endorsement of different leadership theories. 


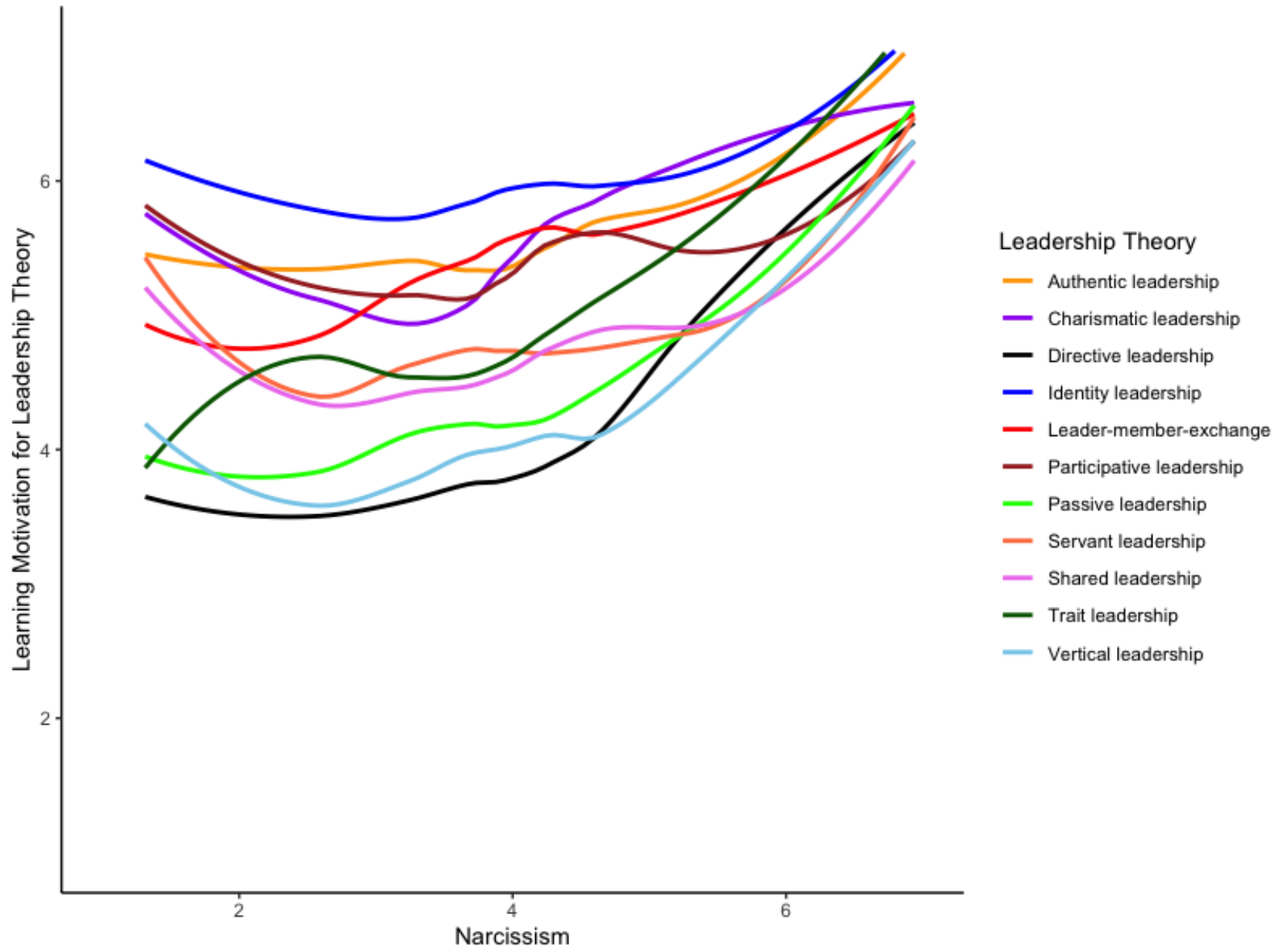

Figure 2. Associations between narcissism (NPI-16) and motivation to learn about different leadership theories. 